\title{
METHYL TESTOSTERONE IN PREMATURE INFANTS
}

\author{
BY \\ URSULA JAMES and B. L. COLES \\ From the General Lying-In and Annie McCall Hospitals, London
}

(RECEIVED FOR PUBLCATION OCTOBER 18, 1951)

It is an established fact that testosterone compounds cause a reduction in urinary nitrogen excretion which affects mainly the urea fraction. The faecal nitrogen excretion remains unaltered, leading to a nitrogen retention in the tissues. The haemoglobin, plasma protein, non-protein nitrogen and urea concentrations in the blood are unchanged. The urinary sodium, chloride, potassium and phosphorus are reduced. The net result is a gain in weight due to water retained by the electrolytes and protein. The gain exceeds any possible increase accounted for by enlargement of genital tissue and represents true somatic growth. After testosterone is discontinued there is a rapid loss of water, sodium and chloride from the body, potassium and phosphorus are slowly excreted, but nitrogen remains in the tissues for some weeks. Similar results have been observed in eunuchoids and in normal controls of both sexes (Kenyon, Knowlton and Sandiford, 1944; Kenyon, Knowlton, Sandiford, Koch and Lotwin, 1940).

This property of testosterone to promote nitrogen retention suggests a possible use in the treatment of premature infants to promote a more rapid weight gain. Several reports of its use in this connexion have been published in the American literature. Shelton and Varden (1946) treated 15 premature infants with birth weights of less than 1,920 g. (4 lb.) with methyl testosterone $(2 \cdot 5 \mathrm{mg}$. 12-hourly for three to seven weeks). Their initial weight losses were reported to be minimal and subsequent weight gain and vigour were initiated early. No undesirable side-effects were noted. In further papers (Shelton, Varden and Mark, 1947; Shelton and Mark, 1948) 74 prematures were divided into three groups. Twenty were used as controls, 30 received methyl testosterone, $5 \mathrm{mg}$. daily in propylene glycol, and 24 were given $4 \mathrm{mg}$. of testosterone propionate daily by intramuscular injection. Treatment was started at 12 hours and continued for three weeks. The cases were further sub-divided according to birth weight, $1,000-1,500 \mathrm{~g}$. and 1,500-2,000 g. Of those with the lower birth weights the controls took an average of 14.7 days to regain their birth weight, those receiving methyl testosterone averaged nine days, and those receiving testosterone propionate $7 \cdot 5$ days. Of the cases with birth weights of 1,500 $2,000 \mathrm{~g}$., the controls took an average of 11.9 days to regain their birth weight, those on methyl testosterone $7 \cdot 8$ days and those on testosterone propionate 9.8 days. The treated cases also reached the weight of $2,500 \mathrm{~g}$. significantly earlier than the controls. Four sets of twins were also investigated. In three sets the larger twin acted as control and the smaller twin received testosterone. In all four sets the treated twin was the first to reach both birth weight and 2,500 g. No difference between the two compounds used was noted apart from the greater accuracy of dosage possible with the intramuscular testosterone propionate, and no side effects were seen. Tittle (1949) reported 18 premature infants with birth weights ranging from $3 \mathrm{lb}$. to $4 \mathrm{lb}$. $13 \mathrm{oz}$. These were given $2 \cdot 5 \mathrm{mg}$. testosterone 12-hourly from 24 hours until $5 \mathrm{lb}$. was reached. These cases were compared with infants born during the previous year of comparable birth weight. The treated cases showed a $45 \%$ decrease in the number of days taken to regain their birth weight and a $32 \%$ advantage in reaching $5 \mathrm{lb}$.

Hardy and Wilkins (1949), however, found that 26 infants given $2.5 \mathrm{mg}$. of methyl testosterone 12-hourly starting between the seventh and tenth day and continuing for four weeks showed no significant advantage over 26 control cases with a similar feeding regime. Two of these cases developed moderate enlargement of the penis and several females had transient enlargement of the clitoris. Seitchik and Agerty (1950) treated 27 premature infants with birth weights of 1.3 to $2.3 \mathrm{~kg}$. with $2.5 \mathrm{mg}$. of methyl testosterone 12-hourly and compared them with 30 controls. The percentage of nitrogen retained was slightly higher in the treated cases, but there was no marked difference in the time taken to regain birth weight, to reach $2.5 \mathrm{~kg}$., or in the percentage of birth weight attained during the period of study in the two groups. Reilly and Earle (1951) found no difference between the progress of 25 premature infants given $5 \mathrm{mg}$. methyl testosterone in propylene glycol daily and 25 control prematures. Therapy started between the fourth and eighteenth days 
(average tenth day) and was continued for an average of 24 days.

\section{The Present Investigation}

The present investigation, which lasted for one year, was undertaken to determine (1) if methyl testosterone had any effect on the rate of weight gain in premature infants, and (2) if the effect of methyl testosterone was enhanced by simultaneous high protein feeding.

The investigation was conducted at two maternity hospitals and the cases were divided as follows:

Hospital X (General Lying-In Hospital). All infants were divided into three groups according to birth weight. Group (1) birth weight $4 \mathrm{lb} .8 \mathrm{oz}$.$5 \mathrm{lb} .8 \mathrm{oz}$; Group (2) birth weight $3 \mathrm{lb} .8 \mathrm{oz} .-4 \mathrm{lb}$. 7 oz.; Group (3) birth weight under $3 \mathrm{lb} .8 \mathrm{oz}$.

Alternate cases were further subdivided into Groups A and B. Group A received 'casinal ', 1 g. per lb. of birth weight per day, from the third or fourth day according to when feeding began. Group B received 'casinal' as in Group A together with methyl testosterone (Ciba) $5 \mathrm{mg}$.

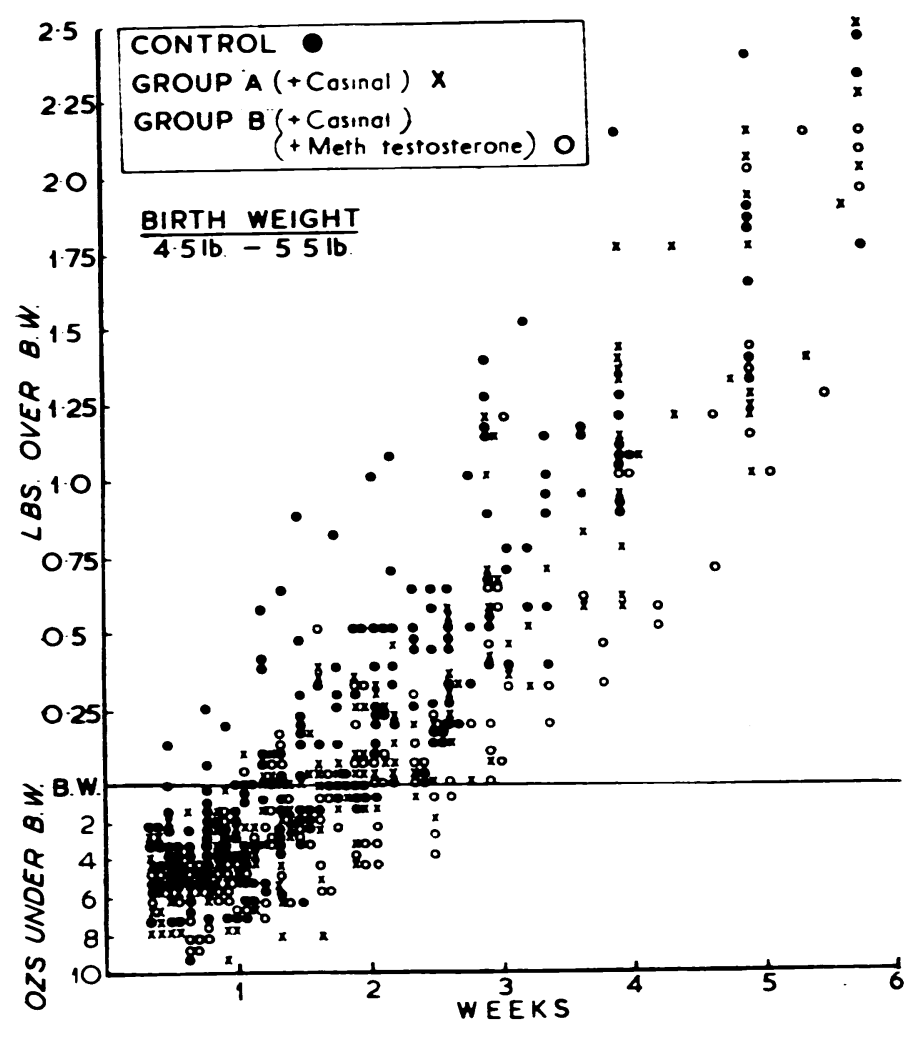

Fig. 1. daily by mouth. This was continued until the infant was discharged, or for 28 days in cases where prolonged hospital treatment was required. These cases were compared with premature infants born in the same unit in 1948-49, and subject to the same feeding methods.

Hospital Y (Annie McCall Matemity Hospital). Cases were divided into similar weight groups and further subdivided into Groups C and D. Group $C$ acted as controls. Group D received methyl testosterone, $5 \mathrm{mg}$. by mouth, daily from the first or second day. The testosterone was given during the stay in hospital or for 28 days as in Hospital X.

At both hospitals the feeding regime was the same. Breast milk was fed whenever possible. Where this was not possible half cream Cow and Gate made up to 20 calories per ounce was used. Seven calories per pound of birth weight were given on the first day of feeding, and this was increased in multiples of seven calories up to 50 calories per pound on the seventh day. Further increases over 50 calories per pound were made when tolerated. Breast feeding was initiated early in some cases, in others various forms of hand feeding were employed as indicated by the vigour of the infant. No subcutaneous fluid was given in any case. In all cases except 10 in Groups 2 and 3 feeding was started on the first or second day of life. In the other 10 feeding began on the third day. Vitamins $A$ and $D$ were added on the tenth day and vitamin $C$ on the fourteenth. The criteria of progress adopted were the number of days taken to regain birth weight, and the weight gain over and above birth weight at the age of 1 month.

At Hospital $X$ the minimum number of days of treatment was six days (one case), the maximum 28 days, and the average 15 days. At Hospital $Y$ the minimum number of days in which testosterone was given was 10 , the maximum 28 and the average 17.6. All cases at this hospital were started on feeds on the first or second day of life.

\section{Results}

The days taken to regain birth weight in Groups 1 and 2 at both hospitals are shown in Tables 1 and 2 . The average time taken for treated cases to regain birth weight was slightly longer than in the controls, 
but the differences are not conclusive. The number of Group 2 cases seen at Hospital $Y$ are too small to draw any conclusions and no Group 3 cases were seen at this hospital.

The Group 3 cases at Hospital X were all Group B and the results are given in Table 3. The two Group A cases both died during the first fortnight, one from congenital heart disease and one from bronchopneumonia, and they are therefore excluded from this series.

Figs. 1 and 2 show the weights of control and treated cases at Hospital $X$ plotted at various ages. No significant difference between the two is apparent. Fig. 3 shows similar scatter for both Group 1 and 2 cases from Hospital $Y$.

Table 4 shows the gain over birth weight attained at 1 month of age at Hospital X. Not all the original cases returned for follow-up at this age, so that the numbers compared are less than those treated in the hospital.

Results for cases from Hospital Y are given in Table 5 .

The average weight gain in all treated cases is slightly lower than in the controls in all weight groups.

TANE 1

Days Taken to Regan Bint Wegrt at Hosmal $X$

\begin{tabular}{|c|c|c|c|c|c|c|}
\hline \multirow[b]{3}{*}{ No. of Cases } & \multicolumn{3}{|c|}{ Group 1} & \multicolumn{3}{|c|}{ Group 2} \\
\hline & $\overline{\text { Control }}$ & $\mathbf{A}$ & B & Control & $\mathbf{A}$ & B \\
\hline & 37 & 20 & 14 & 10 & 6 & 7 \\
\hline $\begin{array}{l}\text { Minimum days to } \\
\text { regain birth weight }\end{array}$ & 0 & 8 & 7 & 8 & 8 & 10 \\
\hline $\begin{array}{l}\text { Maximum days to } \\
\text { regain birth weight }\end{array}$ & 17 & 19 & 20 & 13 & 21 & 21 \\
\hline $\begin{array}{l}\text { Average days to } \\
\text { regain birth weight }\end{array}$ & $10 \cdot 8$ & $11 \cdot 7$ & $13 \cdot 3$ & $10 \cdot 5$ & $14 \cdot 1$ & $14 \cdot 2$ \\
\hline
\end{tabular}

TABUE 2

Days Taken to Regan Brth Weght at Hosptial $Y$

\begin{tabular}{|c|c|c|c|c|}
\hline \multirow[b]{3}{*}{ No. of Cases } & \multicolumn{2}{|c|}{ Group 1} & \multicolumn{2}{|c|}{ Group 2} \\
\hline & Group C & Group D & Group C & Group D \\
\hline & 12 & 8 & 3 & 2 \\
\hline $\begin{array}{l}\text { Minimum days to } \\
\text { regain birth weight }\end{array}$ & $\mathbf{0}$ & 5 & 5 & 12 \\
\hline $\begin{array}{l}\text { Maximum days to } \\
\text { regain birth weight }\end{array}$ & 16 & 17 & 14 & 15 \\
\hline $\begin{array}{l}\text { Average days to } \\
\text { regain birth weight }\end{array}$ & $8 \cdot 8$ & $9 \cdot 1$ & 8 & $15 \cdot 5$ \\
\hline
\end{tabular}

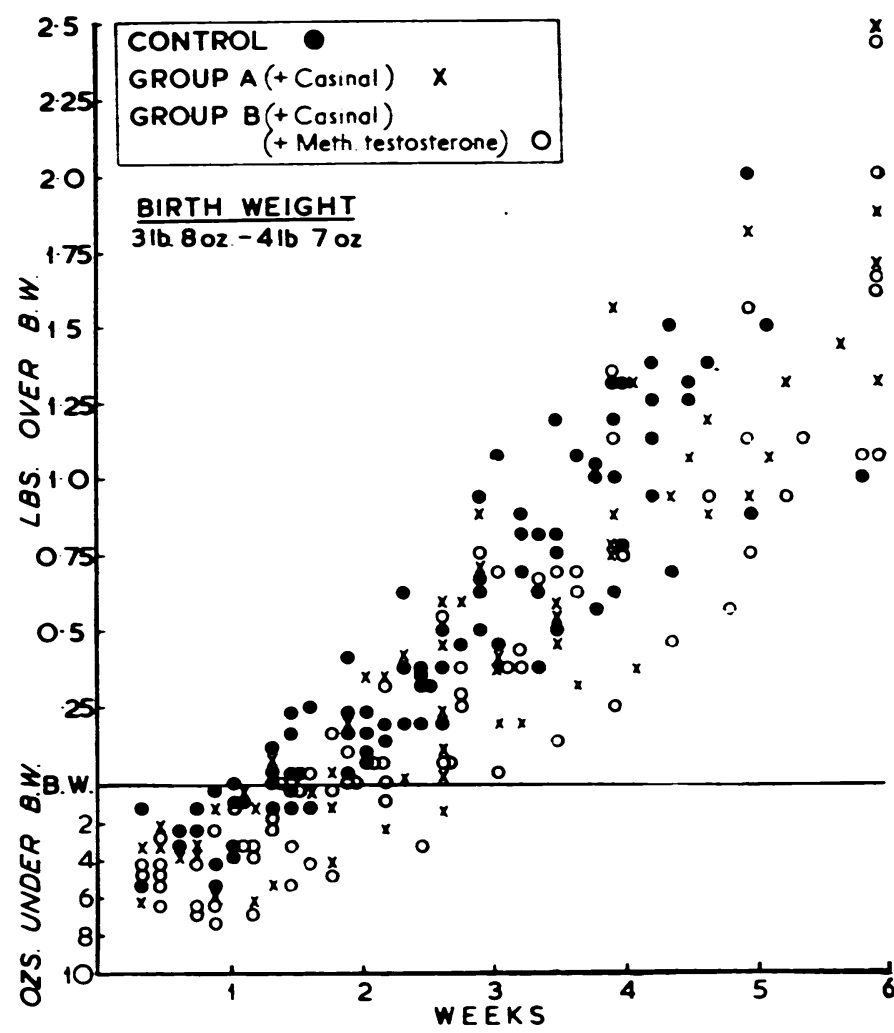

Fig. 2. 
TARe 3

Weght Gains of Group 3 Cases at Hospttal $X$

\begin{tabular}{|c|c|c|c|c|c|c|c|}
\hline \multirow[b]{3}{*}{ Control } & \multirow{2}{*}{\multicolumn{2}{|c|}{$\begin{array}{c}\text { Birth } \\
\text { Weight }\end{array}$}} & \multirow{3}{*}{$\begin{array}{c}\begin{array}{c}\text { Days to } \\
\text { Regain } \\
\text { Birth } \\
\text { Weight }\end{array} \\
23\end{array}$} & \multicolumn{4}{|c|}{ Weight Gain } \\
\hline & & & & \multicolumn{2}{|c|}{1 month } & 2 months & 3 months \\
\hline & & oz & & lb. & oz & $\underset{2}{\text { lb. }} \quad$ oz & lb. $\frac{\text { oz }}{8}$ \\
\hline Control & 3 & 6 & 14 & 1 & $\mathbf{0}$ & 114 & 8 \\
\hline Treated & 3 & 6 & 14 & & 15 & 2 & - \\
\hline Treated & 3 & 10 & 20 & & 6 & - & - \\
\hline Treated & 2 & 10 & 25 & & 11 & 3 & 4 \\
\hline
\end{tabular}

(1944) state that epiphyseal closure is not readily induced and that prolonged and heavy dosage is necessary to produce it.

As no oedema was seen in cases following the administration of testosterone, it appears that the nitrogen retention induced by this substance does not lead to water retention in the form of clinical cedema. If water retention is responsible for any gain in weight it must be utilized for true somatic

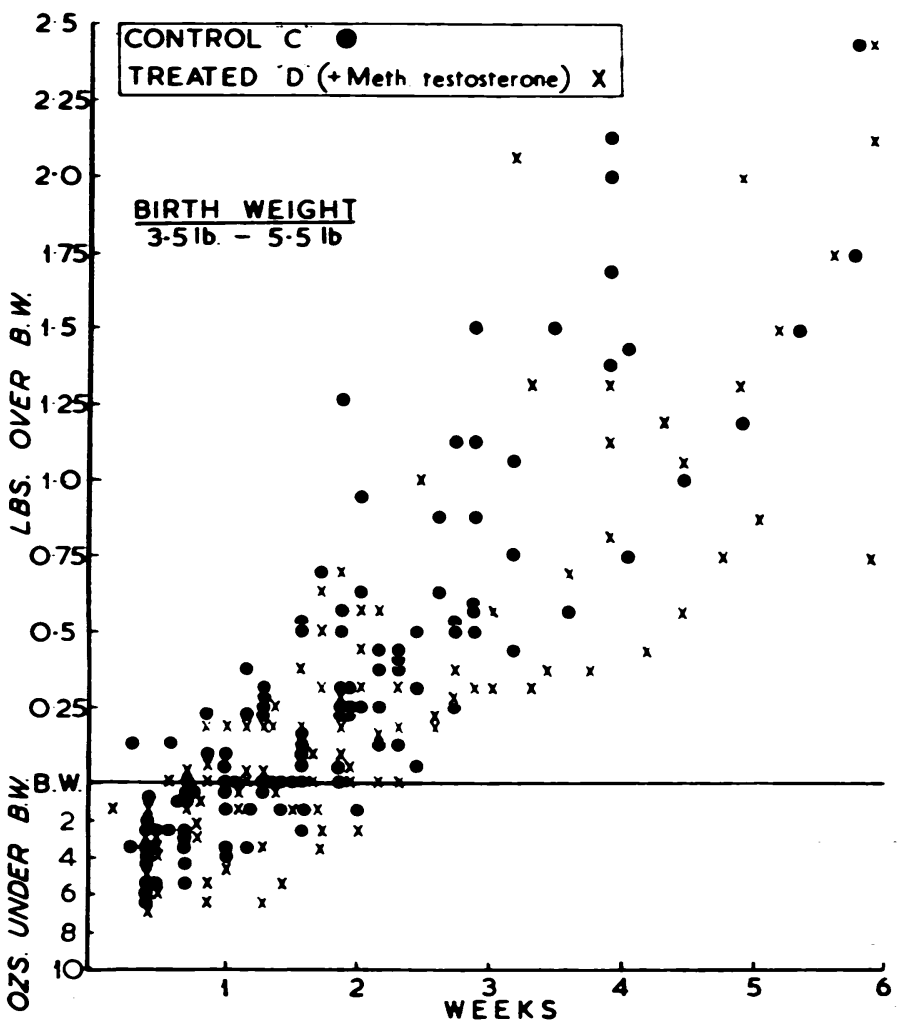

Fig. 3.
TAmex 4

Weght gans at 1 Month of Age at Hosptial X

\begin{tabular}{|c|c|c|c|c|c|c|}
\hline \multirow[b]{3}{*}{ No. of Cases } & \multicolumn{3}{|c|}{ Group 1} & \multicolumn{3}{|c|}{ Group 2} \\
\hline & Control & $\mathbf{A}$ & B & Control & $\mathbf{A}$ & B \\
\hline & 15 & 15 & 11 & 9 & 6 & 7 \\
\hline $\begin{array}{l}\text { Maximum } \\
\text { weight gain }\end{array}$ & $\begin{array}{c}\text { lb. oz. } \\
23\end{array}$ & $\begin{array}{l}\text { lb. oz. } \\
115\end{array}$ & $\begin{array}{l}\text { lb. oz. } \\
110\end{array}$ & $\begin{array}{r}\text { lb. oz. } \\
16\end{array}$ & $\begin{array}{l}\text { lb. oz. } \\
110\end{array}$ & $\begin{array}{l}\text { lb. oz. } \\
16\end{array}$ \\
\hline $\begin{array}{l}\text { Minimum } \\
\text { weight gain }\end{array}$ & 8 & 10 & 7 & 10 & 8 & 5 \\
\hline $\begin{array}{l}\text { Average } \\
\text { weight gain }\end{array}$ & 141 & $13 \frac{1}{2}$ & $13 \frac{1}{2}$ & 1 & 10 & $13 \underline{\underline{2}}$ \\
\hline
\end{tabular}

growth. No investigations to demonstrate increased nitrogen retention were made in this series, but the dosage of methyl testosterone was the same as in cases where this had been shown (Seitchik and Agerty, 1950) so that it was unlikely that inadequate dosage was responsible for our failure to obtain weight gain. Seitchik and Agerty, however, question whether adequately nourished prematures respond to the theoretical growth stimulation of testosterone, and are supported by Beattie (personal communication) who found that adults only responded by weight increase and marked nitrogen retention where previous physiological stresses, i.e. infections, trauma, etc., were a prominent feature. Normal adult controls failed to show any appreciable results when treated with testosterone. Shelton and Varden (1946) and Tittle (1949) started testosterone during the first 24 hours and claimed significant results, whereas Hardy and Wilkins (1949) began treatment on the seventh to tenth day and were unable to show that it accelerated growth. Our cases at Hospital Y started testosterone on the first or second day and those at Hospital $X$ on the third or fourth day. We feel that it is unlikely that a delay of 24 to 48 hours in starting therapy has made a significant difference to our results. The duration of treatment in this series was less than in other reported cases, but once an infant was sufficiently established to leave hospital there seemed little point in continuing testosterone, and we felt that the uncertainties of dosage inherent in domiciliary administration would 
TARLE 5

Weight Gan at 1 Month of Age at Hosptial $Y$

\begin{tabular}{|c|c|c|c|c|c|c|c|c|}
\hline \multirow[b]{3}{*}{ No. of Cases } & & \multicolumn{4}{|c|}{ Group 1} & \multicolumn{3}{|c|}{ Group 2} \\
\hline & & \multirow{2}{*}{\multicolumn{2}{|c|}{$\frac{\text { Control }}{6}$}} & \multirow{2}{*}{\multicolumn{2}{|c|}{$\frac{\text { Treated }}{6}$}} & \multirow{2}{*}{\multicolumn{2}{|c|}{ 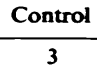 }} & \multirow{3}{*}{$\begin{array}{c}\text { Treated } \\
2 \\
\text { oz. } \\
14\end{array}$} \\
\hline & & & & & & & & \\
\hline $\begin{array}{l}\text { Maximum } \\
\text { weight gain }\end{array}$ & . & $\begin{array}{l}\text { lb. } \\
2\end{array}$ & $\begin{array}{r}\text { oz. } \\
2\end{array}$ & $\begin{array}{l}\text { lb. } \\
2\end{array}$ & $\begin{array}{r}\text { oz. } \\
8\end{array}$ & & $\begin{array}{r}\text { oz. } \\
0\end{array}$ & \\
\hline $\begin{array}{l}\text { Minimum } \\
\text { weight gain }\end{array}$ & . & 1 & 1 & & 14 & & 13 & 6 \\
\hline $\begin{array}{l}\text { Average } \\
\text { weight gain }\end{array}$ & . & 1 & 11 & 1 & 11 & 1 & 8 & 10 \\
\hline
\end{tabular}

have made further treatment valueless from the point of view of a controlled investigation.

We were anxious to ascertain if the addition of protein to standard feeds would in any way enhance the action of testosterone and the group of cases receiving 'casinal' alone was included in order to prove that high protein feeding itself was not responsible for any accelerated weight gain.

Consideration of the results from the two hospitals makes it plain that the simultaneous administration of protein and testosterone has no advantage. This is not in accordance with the work of Earle (1951) who noted appreciable difference in weight gain and shorter hospital stay in 13 premature negro infants who were given methyl testosterone. $5 \mathrm{mg}$. daily together with $100-150 \mathrm{ml}$. plasma orally a day, until they reached the weight of 2,722 g. These were compared with a control series receiving similar routine treatment and feeding.

\section{Summary}

Fifty premature infants were divided into two groups. Twenty-six received 'casinal', 1 g. per lb. birth weight daily, starting on the third or fourth day. Twenty-four received the same dose of 'casinal 'together with $5 \mathrm{mg}$. methyl testosterone daily by mouth. These were compared with 49 controls from the previous year.

Twenty-five premature infants from another hospital were divided into two groups, 10 receiving 5 mg. methyl testosterone from the first or second day, and 15 were controls.

All groups were further subdivided according to birth weight.

No significant difference in the time taken to regain birth weight or the amount of weight gained over birth weight at 1 month was noted between the treated cases and the controls in any weight group.

No side-effects were noticed as a result of treatment apart from transient enlargement of the clitoris in two cases.

We think it unlikely that the normal adequately nourished premature infant responds to the growth stimulus of testosterone, and in our opinion this hormone is of no value in the rearing of healthy premature babies.

We wish to thank the resident medical officers and the nursing staff of the hospitals concerned for their unfailing co-operation throughout the investigation. We also wish to thank Professor John Beattie for his helpful criticism.

\section{ReFERENCES}

Beattie, J. (1951). Personal communication.

Earle, A. M. (1950). J. Pediat., 36, 87.

Hardy, J. and Wilkins, L. (1949). Ibid., 34, 439.

Kenyon, A. T., Knowiton, K. and Sandiford, I. (1944). Ann. intern. Med., $20,632$.

$-, \frac{26}{26}, \frac{.}{26 .}$, Koch, F. C. and Lotwin, G. (1940). Endocrinology,

Reilly, W. A. and Earie, A. M. (1951). Amer. J. Dis. Child., 82, 323

Seitchik, J. N. and Agerty, H. A. (1950). Pediatrics, 5, 200.

Shelton, E. K. and Mark. J. S. (1948). Calif. Med., $93,39$.

- and Varden, A. E. (1946). J. clin. Endocr., 6, 812.

$\longrightarrow, \frac{1}{7}$ and Mark, J. S. (1947). Ibid., 7, 708. 